\title{
Interpreting the Outsider Tradition in British European Policy Speeches from Thatcher to Cameron
}

Oliver Daddow

od21@leicester.ac.uk

\begin{abstract}
The article investigates how British European policy thinking has been informed by what it identifies as an 'outsider' tradition of thinking about 'Europe' in British foreign policy dating from imperial times to the presen. The article begins by delineating five phases in the evolution of the outsider tradition through a survey of the relevant historiography back to 1815. The article then examines how prime ministers from Margaret Thatcher to David Cameron have looked to various inflections of the outsider tradition to inform their European discourses. The focus in the speech data sections is on British identity, history and the realist appreciation of international politics that informed the leaders' suggestions for EEC/EU reform. The central argument is that historically informed narratives such as those making up the outsider tradition do not determine opinion-formers' outlooks, but that they can be deeply impervious to rapid change.
\end{abstract}

Keywords: Britain; European Union; Discourse Analysis; outsider tradition; David Cameron 


\section{Interpreting the Outsider Tradition in British European Policy Speeches from Thatcher to Cameron ${ }^{1}$}

In terms of its foreign policy orientation Britain has often been labelled a 'stranger in Europe', home to a nation of 'reluctant Europeans', sitting 'on the sidelines' of integration, politically, geographically and emotionally (Gowland and Turner, 1999; Wall, 2008; Gowland et al., 2010). Elite decision-makers in London were extremely cautious about throwing Britain's full weight behind supranational integration initiatives after 1945. On joining the European Economic Community (EEC) in 1973 - known since 1993 as the European Union (EU) - Britain assumed the mantle of 'awkward partner' (George, 1994), locked in an uncomfortable 'semi-detached' relationship with the organization (Jenkins, 1983, p. 147; George, 1992; Callaghan, 2007, pp. 213-214). In this politically charged historical reading (treated in Daddow, 2004) Britain 'missed the bus', was compelled to jump aboard a vehicle London elites judged to be going in the wrong, supranational, direction, but then found interminable problems adapting to a 'Europe cut to a French pattern' (Camps, 1966, p. 45). Britain is not the only EU member or non-member state to be written off as a European laggard (for instance Gstöhl, 2002). However, its position as a large and influential member state that energetically engages in certain integrationist endeavours, while at other times acting as a lightning conductor for countries wishing to fragment the European project in the name of diversity, makes it a compelling focus for academic attention.

The article conceptualizes the 'outsider tradition' (OT for short) in British European policy as a multidimensional package of narratives which sustains the belief, even amongst many of those who profess the benefits of an activist European policy, that Britain is a European actor of an exceptional kind. Drawing on the useful categorization in Nicholas Crowson's (2011) account of the history of the debate about 'limited liability versus

\footnotetext{
${ }^{1}$ I am grateful to the following readers for commenting so helpfully on earlier drafts of this article: Richard Corbett, Alun Munslow, Tim Oliver and Stephen Wall.
} 
continental commitment' in British-European relations, the article contends that unpacking the OT is a fruitful way of appreciating the dynamics of the long-lasting national debate about the 'meaning' of 'Europe' to the British in identity as opposed to material interest terms (insightfully Taylor, 1990). The argument pursued in the article is that we can understand why Britain has come to hover near the EU exit door because British leaders have consistently drawn upon 'outsider' narratives as the organizing frame for their European policy discourses. The article centres on the views of five prime ministers from Margaret Thatcher to David Cameron - taking in John Major, Tony Blair and Gordon Brown in between - expressed in speeches from 1988 to 2013. Together, these five leaders have constructed what is currently held to be the mainstream government discourse on British European policy. Their discourse, remarkably consistent in this period, is held up as the 'establishment' British position against which 'soft' sceptics and avowed, 'hard' EU withdrawal-ists both kick (see the article on UKIP, for example, in this volume). The analysis below reveals that even inside the EEC/EU, British leaders have perpetuated the rhetoric of limited liability, even when policy practice has clearly entrenched the value of the continental commitment.

This argument is advanced in three parts. The first part surveys the historiography of British European policy back to 1815 to suggest that it is a pragmatic British narrative responding to various Europe-related policy dilemmas in British foreign policy by satisfying the competing claims of the exponents of limited liability on the one hand, and continental commitment on the other. The second part delves into the identity-based elements of the OT, with special reference to prime ministerial constructions of British and European identity in speeches from 1988 to 2013. The final part considers the ways in which Britain's European reform proposals, especially on sovereignty and subsidiarity, have adapted rather than done away with earlier manifestations of the outsider tradition. 


\section{The outsider tradition in the historiography}

This article builds on recent work in interpretivist international relations by treating the OT as the discursive rationalization of British diplomatic practices which have arisen, largely reactively, in response to a series of European policy dilemmas. These dilemmas have posed an existential identity-based question to British decision-makers: is Britain a part of Europe or not? Significantly, given its national cultural resonance, the article does not link the OT to any particular domestic political tradition in Britain, preferring to explore how it cross-cuts partisan narratives with 'Atlanticism, pro-Europeanism and pro-Commonwealth ideas' (Bevir et al., 2013, p. 168). It is therefore beyond the scope of the article to trace how specific political traditions such as conservatism, whiggism, socialism and liberalism interplay with the OT. However, this could be a fruitful avenue for onward research and the most obvious are flagged up in the speech data sections below.

The OT in British European policy emerged as a technique for managing (but never resolving) intra-party, Cabinet and Whitehall battles between the proponents of limited liability on the one hand and those pushing for a continental commitment on the other. Clearly, even as an 'outsider' Britain has never been isolated from, or disinterested in, European affairs. London decision-makers often feared the consequences of staying outside formal integration initiatives after 1945 , just as before that time they feared a shift in the balance of power on the continent which might threaten British security or prosperity. As Austen Chamberlain, Foreign Secretary in Stanley Baldwin's Labour government of 1924-29, explained: 'The fact is that we have never been able to free ourselves from the conditions which geography has set for us, and if that same geographical position has been the origin of our colonizing enterprise and world-wide empire, it has not less clearly determined that we cannot separate our fortunes from those of Europe' (Chamberlain, 1930, p. 183). The 
question has been, therefore, not the false one between isolationism or engagement, but what depth and manner of European engagement is appropriate to sustain the sense of self the British have sought to acquire for themselves, and to enable them to translate that self-image into a workable foreign policy that helps make the world safe for the realization of British interests. As the table below illustrates, the OT has developed as a grand narrative tradition within which these dilemmas have been thought about, managed (or put off) and legitimated publicly through political discourse. As Vivien Schmidt remarks (2000, p. 278), this is all about the creation and projection of 'a coherent vision of how the nation fits into an integrating Europe and a globalizing world'. The study of political language helps us ascertain how those discursive structures - called here traditions - have evolved, sedimented in policy thinking, and mutated over time in response to dilemmas. Several different manifestations of 'outsider-liness' have been in evidence, and the phases identified below reflect critical junctures in the historiography on British-European relations over the past two centuries.

Table 1: The Outsider Tradition in British European Policy

\begin{tabular}{|l|l|l|}
\hline Phase and dates & Dilemmas faced & Policy orientation \\
\hline $\begin{array}{l}\text { PHASE 1 } \\
\text { 1815-1939 }\end{array}$ & $\begin{array}{l}\text { Development and } \\
\text { management of Empire } \\
\text { Rise and fall of potential } \\
\text { European hegemons, } \\
\text { particularly France and } \\
\text { Russia }\end{array}$ & $\begin{array}{l}\text { Outsider as balancer } \\
\text { Stay out of European politics } \\
\text { and conflicts unless } \\
\text { compelled by force of events }\end{array}$ \\
World War One \\
1939-1955 & $\begin{array}{l}\text { World War Two and early } \\
\text { Cold War years } \\
\text { Imperial overstretch and } \\
\text { early years of decolonization, } \\
\text { for example in India }\end{array}$ & $\begin{array}{l}\text { Outsider as supporter } \\
\text { Encourage unity, associate } \\
\text { with initiatives, eg ECSC, } \\
\text { and sometimes provide } \\
\text { leadership, eg WEU. } \\
\text { Maintain UK commitment to } \\
\text { the defence of Western }\end{array}$ \\
\hline
\end{tabular}




\begin{tabular}{|c|c|c|}
\hline & $\begin{array}{l}\text { Loss of 'great power' status } \\
\text { (rise of US and Russia) } \\
\text { Economic degradation }\end{array}$ & $\begin{array}{l}\text { Europe, via NATO and } \\
\text { British Army of the Rhine. }\end{array}$ \\
\hline $\begin{array}{l}\text { PHASE 3a } \\
1955-1956\end{array}$ & $\begin{array}{l}\text { Revival of supranational } \\
\text { approach to European } \\
\text { integration } \\
\text { Decolonization continuing }\end{array}$ & $\begin{array}{l}\text { Outsider as saboteur } \\
\text { Turn US against common } \\
\text { market and tempt key nations } \\
\text { such as Germany towards } \\
\text { looser trading arrangements }\end{array}$ \\
\hline $\begin{array}{l}\text { PHASE 3b } \\
\text { 1956-1960 }\end{array}$ & $\begin{array}{l}\text { Successful conclusion of } \\
\text { Spaak Committee } \\
\text { negotiations } \\
\text { Suez Crisis and Anglo- } \\
\text { American tensions }\end{array}$ & $\begin{array}{l}\text { Outsider as rival } \\
\text { Damage limitation via failed } \\
\text { attempt to negotiate a } \\
\text { European free trade area and } \\
\text { successful creation of EFTA }\end{array}$ \\
\hline $\begin{array}{l}\text { PHASE } 4 \\
\text { 1960-1973 }\end{array}$ & $\begin{array}{l}\text { Structural shifts in global } \\
\text { trade patterns } \\
\text { 'Winds of change' blowing } \\
\text { through Empire } \\
\text { Emergence of 'declinist' } \\
\text { thesis in British politics }\end{array}$ & $\begin{array}{l}\text { Outsider as supplicant } \\
\text { France vetoed first two } \\
\text { applications, but negotiations } \\
\text { hampered throughout by } \\
\text { tactics, eg on Commonwealth } \\
\text { preferences }\end{array}$ \\
\hline $\begin{array}{l}\text { PHASE } 5 \\
\text { 1973-2017 }\end{array}$ & $\begin{array}{l}\text { Adapting to EEC } \\
\text { membership and transition } \\
\text { from EEC to more } \\
\text { supranational EU } \\
\text { 'Second Cold War' in } 1980 \text { s } \\
\text { and end of Cold War in } 1989 \\
\text { Public and media scrutiny of } \\
\text { European affairs: issue } \\
\text { management } \\
\text { Party political splits over } \\
\text { 'Europe' }\end{array}$ & $\begin{array}{l}\text { Outsider as insider } \\
\text { Leadership on issues such as } \\
\text { Single European Market and } \\
\text { deregulation, accompanied } \\
\text { by disputes over budget and } \\
\text { British rebate. Increasing use } \\
\text { of opt-outs in politically } \\
\text { sensitive matters. Possibility } \\
\text { of withdrawal from EU after } \\
\text { referendum. }\end{array}$ \\
\hline
\end{tabular}

\section{Phase 1}

The first phase covers the rise of the British Empire, which was built from the time of American independence in 1783 to 1939 , and developed into a global strategy after the defeat 
of Napoleon in the nineteenth century, when Britain energetically pursued imperial expansion in Africa, Asia and the Pacific. The corollary in Europe was limited liability, whereby Britain acted as a power balancer against continental threats and adversaries. There were periods of active leadership in the form of a continental commitment, for example in creating and sustaining the Concert of Europe from 1815. Nonetheless, Foreign Secretary Robert Castlereagh summed up the preferred British position in a paper of May 1820 in which he wrote that Britain came into its own 'when actual danger menaces the system of Europe'. Without imminent threat, he went on, 'this country cannot and will not act upon abstract and speculative principles of precaution' (quoted in Goodlad, 2008, p. 13). This conservative reading of international affairs has been in the ascendancy in British European policy thinking since this time, as the final section of the article will demonstrate. The French, Russian and latterly the German threats to Britain's European and imperial interests were persistent concerns for British statesmen in this period (Turner, 2010, pp. 1-5). This phase culminated in the turbulent interwar years 1919-1939 when 'despite increasing pressures to involve itself in continental affairs, Britain preferred to support a balance of power in Europe from the outside, as the best way to preserve its liberal institutions, its world trade and its military security' (Young, 2000, p. 3).

Interwar proposals for European co-operation were more often than not put together by individuals and groups outside of Britain, supporting Michael Gehler and Wolfram Kaiser's argument (2001, pp. 785-786) that the impetus towards transnational co-operation and the pooling of sovereignty in Europe was a much more pressing concern for continental opinion formers than for their British equivalents. For instance, Austrian Count CoudenoveKalergi led the 'pan-European' movement that flourished after World War One. He was dismissed by Sir William Tyrell, Permanent Under-Secretary at the Foreign Office, as 'a thoroughly impractical theorist' (quoted in Young, 2000, p. 4. See also Crowson, 2011, pp. 
19-29). In line with the pragmatic, conservative reading of foreign affairs, this has come to be a characteristic British refrain against plans for unity, as we shall also see later. Other notable unity-related proposals in this period were met with similar scepticism in Britain on economic, political and security grounds. They included the 1926 plan for an international steel cartel and its proposed extension in 1929-30 via the offer of European Union by French foreign minister Aristide Briand (Crowson, 2011, pp. 29-30). Churchill's words from 1930 were emblematic of the British approach in the interwar years: 'we have our own dream and our own task. We are with Europe, but not of it. We are linked but not comprised. We are interested and associated but not absorbed' (cited Crowson, 2011, p. 31).

\section{Phase 2}

The period from 1939 to near the end of 1955 was themed around a strenuous war effort, the resulting economic retrenchment and Cold War insecurity. In these years British foreign policy thinking remained fairly consistent in tone and substance, despite the shift from wartime coalition, through reforming 'socialist' Labour government in 1945-51, and finally to Conservative government in 1951-55. As during Phase 1 there was no consistent immersion by British political parties in the transnational political networks that evolved from 1945, such as the Geneva Circle and Nouvelles Equipes Internationales (Gehler and Kaiser, 2001). Establishment Britain encouraged European unity whilst wishing to maintain a free hand in line with the limited liability conception of Britain's global role articulated by Churchill (Younger, 1972, p. 580). Security and defence considerations featured prominently in Britain's largely negative response to European integration initiatives in the 1950s, as, critically, did the economics of the imperial preference system (Smith, 1950, p. 474). Part of the reason for the concentration on financial affairs was institutional, in that the Treasury dominated the direction of policy towards European co-operation 'in a fashion which 
infringed neither essential UK independence nor the rival claims of the Commonwealth and Atlantic linkages' (Ludlow, 2003, p. 88). The economic departments were sceptical of any European initiative which threatened to undermine Britain's world trading role. Layered on top of these already formidable objections was an ideological component, manifested as the sovereignty-degrading aspects of involvement in a European collective (Callaghan, 2007, p. 202; Young, 2000, p. 15).

In Europe and globally, moreover, the Cold War was hotting up. Britain's support for the defence of Western Europe largely came via the stationing of 50,000 personnel in the British Army of the Rhine (BAOR), maintained as part of its commitment to the USdominated North Atlantic Treaty Organization (NATO) (see Aldrich 2008). ${ }^{2}$ By February 1949, limited liability towards Europe in the context of a grand strategy aimed at consolidating 'Europe, the Commonwealth and America into a "natural unit"' had become agreed British foreign policy strategy (Young, 2000, p. 23). Decision-making in this period lay in the hands of avowed 'Cold War warriors' such as Churchill, Attlee and Bevin, who came to think mainly 'in terms of Britain's traditional role of creating a balance of power on the continent' and 'did not see why Britain had to get involved in European structures' (Turner, 2010, p. 54). Britain resolutely stayed out of the Schuman Plan for a European Coal and Steel Community (ECSC) whilst seeking association from without. Such European entanglements as were sanctioned centred on intergovernmental organizations such as the 1948 Council of Europe. Meanwhile, in 1954, Anthony Eden rescued European defence cooperation in the aftermath of the failed European Defence Community (EDC) proposal through the creation of Western European Union (WEU). However, 'the high point of the British contribution to European unity' would not last long (Deighton, 1998, p. 196). London underestimated the desire of the Six to press ahead with expanded economic co-operation,

\footnotetext{
${ }^{2}$ I am grateful to Jocelyn Mawdsley for reminding me of the military dimension here.
} 
and might have been alerted by the disdainful verdict on WEU delivered by Robert Schuman in October 1954: 'a London façade in the English style, decorated in the Parisian way' (quoted in Gehler and Kaiser, 2001, p. 791). By the end of 1955 the OT had clearly become the leitmotif of British European policy, an achieved and ascribed identity which resonated in and outside Whitehall.

\section{Phase 3}

The next four years, 1956-60, saw a rapid burst of innovation in the OT as London policymakers, caught on the back foot, struggled to devise a coherent response to the rélance of integration at Messina. First, Britain made a short-lived attempt to sabotage the Six's integrationist ambitions (Phase 3a). It then embarked on a period of competition with them by trying to launch a rival British-led European project (Phase 3b). British European policy in this phase has been described appropriately by the historian John Young as transitioning from from 'benevolent neutrality' to 'sabotage' (Young, 2000). Probably for the very reason that Britain's initial attempt to engage with supranational integration was to kill it off, developments in the OT in Phase 3 have tainted the making, packaging and reception of British European policy to the present day. All UK leaders have had to head off potential charges of betrayal when setting out alternative visions for the future of European integration (see below).

Phase 3a followed Britain's withdrawal from the Spaak Committee negotiations on the EEC in November 1955, after which Britain tried to talk the US out of supporting the Messina exercise. London also sought to exploit divisions within the German government between Europeanists and free trade liberals in a bid to persuade the latter against backing the common market idea. Crucially in this period Britain did not proffer an alternative (Schaad, 1998, pp. 44-46 and p. 49). Rebuffed, the British then tried devising a substitute to the EEC 
in the form of Plan G in the 'rival' Phase $3 b$ - 'a free trade area comprising the seventeen member countries of the OEEC [Organisation for European Economic Co-operation], surrounding and including the common market planned by the Messina six' (Schaad, 1998, p. 42. See also Young, 2000, p. 42; Ellison, 1996, pp. 1-34). Martin Schaad contends that Plan G was not intended as a plot to sabotage the common market negotiations underway in the Spaak Committee through 1956, certainly not in the official gloss put on its announcement. Nevertheless, the sense remains that, although never official policy, such an outcome would have been welcomed by key players such as Chancellor Harold Macmillan who feared 'the revival of [West German] power through economic means. It is really giving them on a plate what we fought two wars to prevent' (cited Schaad, 1998, p. 50). After two years of fraught and sometimes acrimonious negotiations, London fell back on a larger but looser European Free Trade Area (EFTA), comprising six other non-Messina states which shared Britain's distaste for supranational integration, but which also feared economic discrimination from operating outside a European customs union. Ironically, however, the creation of EFTA in 1959 'only brought forward the date when the common-market countries adopted a common external tariff' (Callaghan, 2007, p. 203).

\section{Phase 4}

By the end of Phase 3 in 1960 the OT in British European policy had transformed in just a few years from support and encouragement, through attempted sabotage, and finally to the creation of a rival intergovernmental bloc aimed at protecting British economic interests. In Phase 4 Britain radically re-evaluated its European policy in light of 'a growing sense of national malaise' emanating from 'social divisions, economic failure and loss of purpose' that the creation of an alternative European project had done little to diminish (Young, 2000, p. 65). Significantly, given the Treasury's whip-hand over the decision-making process, it was 
civil servants in the economic ministries who were most influential in suggesting that EEC membership would proffer two sets of solutions to the 'British problem'. First, it would help the economy by stimulating growth, attracting US investment, promoting economies of scale and bolstering UK industrial competitiveness. It could not have been lost on the economic gurus in Whitehall that in 1958 the size of the West German economy overtook Britain's for the first time since the Second World War (Callaghan, 2007, p. 203), although as George Peden (2013, p. 60) points out, such trends are more obvious in retrospect than to analysts at the time. Second, British membership of the EEC would promote stability in Cold War Europe, strengthen French-German relations and generally bolster the UK's international influence, particularly with regard to London's standing in the eyes of Washington policymakers (Young, 2000, pp. 65-66).

Politicians such as Foreign Secretary Selwyn Lloyd began to reflect the tenor of these internal discussions in public diplomacy, reorienting British European policy discourse to match the change in thinking. For example, he told the Assembly of the Council of Europe that Britain had been wrong not to join discussions on the ECSC and that 'we regard ourselves as part of Europe, for reasons of sentiment, of history and geography' (quoted in Crowson, 2011, p. 77). Spring 1960 thus marks the beginning of the prioritization within the OT of the narrative of outsider as supplicant. Economic affluence became a key plank in the case 'for' Europe in the heyday of British Europhilia (Beloff, 1963), encouraged by an appreciation that UK trade patterns had decisively shifted from Empire to Europe between 1948 and 1968 (Mackintosh, 1969, p. 251). The Conservative government of Harold Macmillan and the Labour government of Harold Wilson both drew on the emerging Whitehall consensus and applied unsuccessfully to gain membership of the EEC in the period 1961-67 (Ludlow, 1997; Daddow, 2003), before the Conservative government of Edward Heath reactivated the second bid in 1970, negotiating entry from 1 January 1973. 


\section{Phase 5}

Phase 5 covers the EEC/EU membership years from 1973 to the present. It is impossible to recount in detail the troubled history of UK membership, although five pertinent developments in the 'outsider as insider' inflection to the OT are worth mentioning. First, the weight of history, memory and identity questions in Britain's national debates meant that 'Europe' went from being a relatively obscure, technical area of government activity, largely masked from public view and apathetically debated in Parliament (Crowson, 2011, p. 67 and pp. 71-72), to being a hotly contested political issue. European policy since accession has become a significant yet vexatious issue for politicians, advisers, speech writers and spin doctors alike (Daddow, 2011). Second, and resulting from this, rifts over European policy split the Labour Party in the 1980s (Daniels, 1998; Palmer, 1982), led to the creation of a new party by pro-European Labour liberals, and threatened to tear the Conservative Party apart during the ratification of the Maastricht Treaty in the 1990s (Berrington and Hague, 1998, p. 65). The lure of the 'special relationship' and identity questions relating to the EmpireCommonwealth were never far from the surface of these often agonized debates (Bevir et al., 2014, p. 164). Third, and more recently, 'Europe' has helped to recast the political landscape in Britain by creating space for the rise of anti-European and anti-establishment parties such as the Referendum Party and the UK Independence Party (see Tournier-Sol's article in this collection).

Fourth, European integration has increasingly attracted widespread and often negative media coverage in the UK (Wallace, 1986, p. 584 and p. 598; Daddow, 2012), the discredited 'follies of Brussels' being a prime focus of the reportage (Unwin, 1981, p. 396). Finally, a variety of cross-party 'pro' and 'anti' Europe pressure groups have sprung up since EEC membership became a 'live' national political issue in the 1960s (see Forster, 2002). These 
have interacted synergistically with media and political agendas to create a large groundswell of opinion against the EU in Britain on a variety of grounds. Since 2010, and for the first time since Community membership was gained in 1973, withdrawal from the European Union (EU), or the 'Brexit' option (Pertusot, 2013) has come to be been openly debated at the very highest levels of government (Morris, 2013), prompting considerable disquiet amongst key British allies in the EU and globally (Pickard and Parker, 2013; Watt, 2014). The rising salience of the Europe question in British politics resulted in the successful push for two widely watched live television debates on Britain's EU membership between Deputy Prime Minister Nick Clegg and UKIP's Nigel Farage, held in the run-up to the May elections to the European Parliament. Perhaps unsurprisingly, Farage's anti-EU position was widely held to have won the day. The next part of this article examines how political elites have both reflected and fed the sense that Britain is a European actor of an exceptional kind in key speeches on British European policy 1988-2013.

\section{The outsider tradition from Bruges to Bloomberg}

This section argues that at times intentionally, and at others unwittingly, the five premiers from Thatcher to Cameron have been nudging Britain closer to the EU exit door in Phase 5 by popularizing and legitimating different renderings of the OT tradition from Phases 1-4. What they have done, in short, is to underscore Britain's aloofness from its European partners by harnessing imperial nostalgia to the search for a global focused foreign policy strategy which only occasionally, and reluctantly, presupposes a coincidence of 'British' and 'European' interests.

Every UK prime minister emphasized Britain's inextricably European heritage whilst claiming an exceptional status for Britain. This was rooted in the geographical reality of the 
British living an 'island' existence and a nostalgia for empire, together cueing outsider sentiments redolent of the OT that developed in Phases 1-4. They told:

a story of continuity, by contrast with the fickle mutability of the continent, with its constantly changing regimes and borders and monarchs and constitutions; a story of the slow, steady organic growth of institutions, of Common Law, of Parliament, and a unique concept of sovereignty, vested in the Crown in Parliament (Garton Ash, 2001, p. 6).

All the leaders looked to the history of common purpose between Britain and the continent, usually near the beginning of their addresses. Summoning this shared history and heritage, they instructed their audiences on the ways in which Britain had helped fashion European politics and society prior to the creation of the supranational European bus London missed in the 1950s. Gordon Brown put it thus: 'Friends, today there is no old Europe, no new Europe, no east or west Europe. There is only one Europe. Our home Europe.' (Brown 2009). For Brown it was possible to be British and European - the two identities were not mutually exclusive because of the history of common endeavour: 'So I stand here today proud to be British and proud to be European, representing a country that does not see itself as an island adrift from Europe but as a country at the centre of Europe, not in Europe's slipstream but firmly in its mainstream' (Brown 2009).

Conservative premiers delved back further into the past to construct the Britain and Europe story than did Labour leaders, Thatcher's Bruges speech being the densest of the five, historically speaking. She reflected on blood ties and the everyday material experience of 'Europe' in Britain emanating from 'the straight lines of the roads the Romans built' up and down Britain (Thatcher, 1988). In the eleventh and twelfth centuries, she said, Britain was 
'restructured' under Norman and Angevin rule. In the seventeenth century the overthrow of King James II during the Glorious Revolution of 1689 thrust the British crown into the hands of the Dutch Prince William of Orange and his wife Queen Mary. The lesson Thatcher drew from these historical turning points was: 'Visit the great churches and cathedrals of Britain, read our literature and listen to our language: all bear witness to the cultural riches which we have drawn from Europe and other Europeans from us' (Thatcher, 1988).

Compared to Thatcher's heavy chronicle of events, her successors' reading of history was skittish at best. For instance, in his Bloomberg speech of January 2013 Cameron reported that: 'From Caesar's legions to the Napoleonic Wars. From the Reformation, the Enlightenment and the Industrial Revolution to the defeat of Nazism. We have helped to write European history, and Europe has helped write ours' (Cameron, 2103). Every prime minister accepted the EU's official founding myth about the ashes of war stimulating the drive to channel atavistic European nationalism into peaceable, cooperative ventures. Unity, Cameron said in 2009, 'happened because of determined work over generations. A commitment to friendship and a resolve never to re-visit that dark past' (Cameron, 2009). Before him, John Major agreed that: 'The European Community was born to end divisions in Western Europe. It has succeeded' (Major, 1994). Labour's Tony Blair reeled off an 'impressive' roll call of EU achievements: 'peace and stability', 'trade, jobs and growth in Britain and other member states', and the economic and social transformations it has delivered to new member states (Blair, 2002). Gordon Brown added environmental protection and the EU's aid programme into the mix, reflecting on the power of 'human will and courage of representatives with a mission' to rout those who doubted Europe could unite and cooperate' (Brown, 2009).

This said, the the bridge-building between Britain and the continent extended only so far. It is noticeable that the OT has been used to inform the belief that Britain's 'island' status 
conferred upon it an exceptional position with regard to the European project. For instance, Thatcher remarked that aspects of Britain's unique position in this regard came from its sometimes lonely role in helping save Europe, and Europeans, from themselves in times of conflict by acting as 'a home for people from the rest of Europe who sought sanctuary from tyranny' (Thatcher, 1988). Cameron affirmed that 'We have the character of an island nation - independent, forthright, passionate in defence of our sovereignty' (Cameron, 2013). That there has been a strong bipartisan consensus over the 'island' story is evident in Blair's aside - in an otherwise strongly Europhile speech by British standards - that the British are undoubtedly an 'island race' (Blair, 2002). Speaking from this unique vantage point, British leaders have consistently proposed alternative visions of 'Europe' in a bid to reach out to countries thought to be uncomfortable about the drive towards a 'federalist' EU, sparking uncomfortable memories of Britain's 'sabotage' policies in the formative years of the Treaty of Rome.

Thus, the EU's official presentation of its history as vindication of the foresight of the founding fathers was faithfully rehearsed, but with an important caveat from a British perspective: 'Their vision proved right for its age. But it is outdated. It will not do now. We must all adjust our vision to meet the challenges of today and tomorrow' (Major, 1994). Cameron developed Major's point: 'Healing those wounds of our history is the central story of the European Union...But today the main, over-riding purpose of the European Union is different: not to win peace, but to secure prosperity’ (Cameron, 2013). In Conservative leaders' speeches especially, British-European history was told as the tale of hard won national freedoms now imperiled by the rise of an illiberal coercive power across the English Channel - another Armada, Napoleonic army or German tyranny, perhaps. In this way the prime ministers invoked the 'outsider as rival' narrative from Phase 3 by popularizing 'other' 
visions for Europe which could subsume the EEC/EU approach (well covered in Garton Ash, 2001, pp. 4-5).

The alternatives suggested by British leaders reflected time and circumstance, indicating how traditions mutate in response as individuals respond to dilemmas posed by novel or unexpected global events. For example, speaking during the Cold War stand-off, Thatcher asserted that The EEC 'is one manifestation of that European identity, but it is not the only one' (Thatcher, 1988). Behind Churchill's Iron Curtain (see Quinault, 1992, p. 10), she continued, European peoples in cities such as Warsaw, Prague and Budapest 'who once enjoyed a full share of European culture, freedom and identity have been cut off from their roots' (Thatcher, 1988). As European leaders after 1989 grappled with the consequences of German reunification and the prospect of Community enlargement to former Eastern blob countries, Major judged that the European project was incomplete all the 'while so many European democracies remain outside the Union' (Major, 1994). Later, he echoed Thatcher by claiming 'the Poles, the Slovaks, the Hungarians' and other peoples currently on the periphery, such as the Baltic states, were all part of the 'European family' (Major, 1994). A decade later, looking ahead to the largest single expansion of the EU via the incorporation of ten new states in May 2004, Blair judged that it amounted 'to no less than the creation of a new Europe' (Blair, 2002). Having reviewed the ways in which elites since accession have drawn on the OT to justify their opinion that Britain is a 'special sort' of European actor, and that the idea of Europe is 'up for grabs', the following section examines how the policy prescriptions on European reform that flowed from the beliefs about British and European identity the leaders expressed in their speeches.

\section{Sovereignty and subsidiarity: European reform proposals}


Like all member states British leaders have engaged in European reform discussion in a bid to mould the European project in ways more amenable to British interests. Their rhetorical ploy has been to introduce reform proposals as a response to dilemmas posed by the crisis of legitimacy in EEC/EU governance, which has magnified in tandem with increasing contestation over the EU's future direction. In doing so, the prime ministers were adapting the 'outsider as rival' tradition from later Phase 3b. However, where in the later 1950s the British free trade scheme sought to deflect the Six's integration enthusiasm from outside, in Phase 5 London elites claimed to be accepting the basic legitimacy of the EEC/EU and wanting to reform it from inside. As a result, each leader was acutely aware of the propensity for British European policy visions to be interpreted - rightly or wrongly - as a form of Phase 3a 'sabotage' which echoed London's diplomacy towards the US and West Germany at the end of 1955. Liberal reforms of the EU were, therefore, spun by the prime ministers as a response to the existential dilemma of the EU's democratic deficit, one that has gained traction across the EU and its member states, Eurosceptical and Euroenthusiast alike (Simms, 2012, pp. 57-58), especially since the Eurozone crisis and latterly the 2014 European Parliament elections.

In Bruges Thatcher said that Community reform was required otherwise 'we shall not get the public support for the Community's future development', aiming her words on economic competition at an idealized 'European consumer' who would benefit from wider choice and lower costs (Thatcher, 1988). The Conservative focus on the economic benefits from deregulation, free markets and consumer choice was enhanced by Labour leaders in the social democratic tradition. For example, Brown identified consumer rights, workplace rights and social protection as touchstones of European success that needed safeguarding as integration progressed (Brown, 2009). Here, then, national partisan traditions shined through in specific areas of concern for the prime ministers. However, as they moved 'up' a level to 
the crisis in EU governance more generally, partisan differences diminished because the leaders identified problems well recognized outside as well as inside Britain. For example, in 1994 Major argued that the EU 'seems temporarily to have lost the self-confidence of the 1980s. Popular enthusiasm for the Union has waned. We need to listen to these warnings if we are to make the right moves in the future' (Major, 1994). Blair defined the 'democratic deficit' as: apathy, disconnection from citizens, lack of understanding how [the EU] works' (Blair, 2002). Cameron averred: 'People are increasingly frustrated that decisions taken further and further away from them mean their living standards are slashed through enforced austerity or their taxes are used to bail out governments on the other side of the continent' (Cameron, 2013).

Whilst the specific 'targets' of British reform proposals naturally reflected prime ministerial perceptions of the EEC/EU as an institutional construct at the time of their address, their narratives reveal that two significant beliefs remained stable over this period. The first was the realist premise that political change occurs incrementally and practically, not by windy rhetoric or 'abstract theory' (see Hall, 2006, p. 181); the second was that the main agents of change, and focus for peoples' loyalty, remain nation states. Both, in British eyes, cast doubt on the long-term viability of the 'core' European project codified in the Treaty of Rome and its updates Nice, Amsterdam and Lisbon. We will deal with each belief in turn.

Every prime minister wanted to locate him or herself on the realist side of the realistidealist debate in International Relations theory (surveyed in Nau, 2008). This brand of realism is well illustrated by Henry Kissinger's maxim that 'nations live in history, not utopia, and thus must approach their goals in stages' (Kissinger, 1982, p. 585). Drawing on this theoretical tradition, 'The British have a generally well-founded suspicion of pious abstractions in foreign policy; they like to think of their own policy as pragmatic' (Pym, 
1982-83, p. 1). The prime ministers were suspicious of European integration by 'grand design', echoing Churchill's preference for integration that would 'roll forward on a tide of facts, events and impulses rather than by elaborate constitution-making' (Quinault, 1992, p. 9). Hence, Thatcher warned in the Bruges speech: 'The Community is not an end in itself. Nor is it an institutional device to be constantly modified according to the dictates of some abstract intellectual concept' (Thatcher, 1988). The solution, she said, was 'to take decisions on the next steps forward, rather than let ourselves be distracted by Utopian goals. Utopia never comes, because we know we should not like it if it did.' (Thatcher, 1988). Reacting to Conservative Party infighting instigated by the Maastricht Treaty, Major's Leiden speech reads as an extended defence of political realism: 'We do not just want a futuristic grand design which never leaves the drawing board...The most constructive attitude to Europe is to plan a future that works... That is the fact of the matter. We need a vision grounded in reality...The European Union has never lacked for ideas for its development. But it needs ideas which work' (Major, 1994).

This characteristically Conservative take on realism in international relations, expressed as a preference for 'specific institutional responses to demonstrable needs' via prudence and pragmatism (Henig, 1975, p. 492; Harries, 2005, p. 607), also informed New Labour's philosophy of European integration. For example, Blair worried about the propensity for Europe to drift 'into the visionary waters of a European superstate' when what was needed was 'to anchor it properly and clearly where it belongs: with the nations of Europe' (Blair, 2002). Brown was the only one of the five premiers not to entrench a BritishEuropean distinction on rhetoric and reality in international politics. Discussing cooperation, free markets, redistribution and social justice, he said: 'This is not simply our political philosophy - in Europe we believe these truths because we have lived them' (Brown, 2009). All in all, however, the speeches reveal a sequence of leaders propounding the merits of 
cautious incrementalism over abstruse constitutional engineering. Cameron exemplified that outlook by observing that Britain's historically constituted identity has bred in it a certain 'sensibility', meaning a perspective through which 'we come to the European Union with a frame of mind that is more practical than emotional. For us, the European Union is a means to an end - prosperity, stability, the anchor of freedom and democracy both within Europe and beyond her shores - not an end in itself. We insistently ask: How? Why? To what end?' (Cameron, 2013).

The second element of Britain's reform agenda (sovereignty and subsidiarity) evoked the Conservative tradition of nationhood and the libertarian critique of centralization, conformity and centralized planning. Every prime minister identified with former Conservative Foreign Secretary Lord Carrington's opinion that: 'There is strength in diversity, and also in unity', but the trick is to develop 'unity without uniformity' (Carrington, , p. 6). In Bruges, Thatcher presaged much of what followed by arguing that 'willing and active cooperation between independent sovereign states is the best way to build a successful Community' (Thatcher, 1988). She worried that the EEC challenged historically constituted national identities and indicted the Community with various crimes against nationhood. They ranged from an ill-conceived ambition 'to suppress nationhood and concentrate power at the centre of a European conglomerate' to trying to compress nations ‘into some sort of indentikit European personality’ (Thatcher, 1988). Major put the same view: 'I believe the Nation State will remain the basic political unit in Europe' (Major, 1994). Unlike Thatcher, who vilified the European Commission, Major's sights were trained on the European Parliament, which he said made the mistake of seeing 'itself as the future democratic focus for the Union', a flawed belief because 'the European Union is an association of States, deriving its basic legitimacy through national Parliaments' (Major, 1994). Cameron worked the same tradition in his Bloomberg speech: 'There is not, in my 
view, a European demos. It is national parliaments which are, and will remain, the true source of real democratic legitimacy and accountability in the EU' (Cameron, 2013).

Labour leaders paid similar homage to the nation-state in their European policy speeches. However, in line with a collective approach to solving transnational problems in an era of interdependence, Blair and Brown judged this to be a question of 'the challenge of cooperation across borders, of coordination between peoples, and of achieving unity out of diversity' (Brown, 2009). In Cardiff, Blair mimicked Thatcher: 'the driving ideology is indeed a union of nations not a superstate subsuming national sovereignty and national identity' (Blair, 2002). But Blair then diverged from her template by praising the 'carefully balanced' institutional design of the EU, centring on the 'triangle' of Council, Commission and Parliament, backed by the legal rulings of the Court of Justice. 'They represent a quantum leap in democratic governance on an international scale - the pooling of sovereignty in order to extend the reach of democratic action' (Blair, 2002). Thatcherite but only to a degree, Blair adapted the conservative tradition by legitimizing the liberal-friendly theme of pooled sovereignty: 'whilst the origin of European power is the will of sovereign nations, European power nonetheless exists and has its own authority and capability to act' (Blair, 2002). The 'practical' case for pooled sovereignty was a theme of speeches by other influential Labour people during the 1990s (for instance Robertson, 1998). It went some way to transcending what they took to be a limited and inaccurate 'either/or' understanding of sovereignty in the Conservative veneration of nationhood and independence. Moving away from a zero-sum reading of regional power dynamics, New Labour people could foresee circumstances in which European integration moved ahead 'without compromising the identity of the component units, and neither controls the other' (Bogdanor, 2005, p. 699).

Blair's speech also stood out because he recognized the importance to Europe's integrative venture of a favourite UK bête noire, the European Commission. He sympathized 
with those in the political and media classes who castigated it for being a 'remote bureaucracy' taking 'unpopular decisions' but said that it had not always 'managed its internal affairs well' - an allusion amongst other things to the resignation of the Santer Commission amidst accusations of corruption and fraud in 1999 (Ringe, 2003). Nonetheless, Blair believed the Commission was 'essential' as 'the best guarantee of equality in the Union', favouring 'strengthening the Commission's authority in making sure Europe's rules are obeyed' (Blair, 2002). In a small way, this is an example of sites of resistances being created within a dominant discourse, the intention being to persuade audiences of the fallibility of that dominant reading. It was easy to overlook the resistances even in this notionally Europhile speech, however, because Blair's bottom line was that: 'We want a Europe of sovereign nations, countries proud of their own distinctive identity, but cooperating together for mutual good. We fear that the driving ideology behind European integration is a move to a European superstate, in which power is sucked into an unaccountable centre' (Blair, 2002).

The solution to the problem of EU centralization and conformity breeding 'fudge and muddle, bureaucratic meddling' (Blair, 2002) was a robust and enforceable version of subsidiarity which could offset what Thatcher saw as power being 'centralised in Brussels or decisions to be taken by an appointed bureaucracy' (Thatcher, 1988). The main distinction on this issue between Conservative and Labour leaders was therefore on emphasis and presentation. Conservative premiers allied their case for 'no more Europe' to a clear preference for 'less Commission'. By contrast, the Labour agenda assumed greater member state involvement early on in the legislative process, especially in the European Council and Council of Ministers - all in all a more cooperative outlook. For example, Blair saw the subsidiarity principle being enshrined in 'better involvement by national parliaments in European decision-making' (Blair, 2002), with the power to decide whether legislation 
passed the subsidiarity test shifting from Commission and Council to national parliaments via 'new early warning rights' (Blair, 2002). In sum, although leaders of both parties advanced a robust defence of national sovereignty, Conservative leaders believed European institutions to be more dysfunctional than did their Labour counterparts, and hence to present more of an existential threat to British interests.

\section{Conclusion}

This article has argued that several different historiographical conceptions of Britain's 'outsider' status have surfaced in London's European policy discourse and practice from the days of Empire to the present - even when Britain had been inside the EEC for over four decades. Why was this? Because London's policy-makers have struggled to balance the structural imperative of making a continental commitment against their discursively expressed ideological preference for a limited liability policy towards European integration. Through gaining EEC membership in 1973 it appeared that British elites had firmly decided to quash the limited liability approach to European affairs in British foreign policy thinking, replacing it with a continental commitment. Narratives associated with Phase 1 (balancer), Phase 3a (saboteur) and Phase 4 (supplicant) were rejected in favour of an emphasis on the constructive role Britain could play as an 'insider' in Phase 5. Alongside this, they claimed an exceptional status that gave Britain the legitimacy to lead later Phase 3b-style 'rival' approaches to integration, sold using the rhetoric of Phase 2's 'benevolent support'. In this way, 'Europe' has continued to be constructed as a 'club' with a 'membership fee', a grouping that Britain can choose to join or leave as its interests dictate (see Nigel Farage's opening statement in the first television debate (Youtube 2014)).

An interpretivist account of elite discourse from Thatcher to Cameron suggests that, in truth, withdrawal from the EU would be more in line with expressed British identity 
constructions than would continued EU membership, much as this finding might surprise the leaders studied here. No British leader since 1973 has ever proposed that Britain leave the EU

- and yet they have never attempted seriously to challenge the strong notion of outsider-liness underpinning Britain's status as a reluctant partner in the organization. Into this space have stepped a host of anti-European parties and civil society actors, notably in the tabloid and Eurosceptic broadsheet media, who have effectively exploited the lack of purpose in the proEuropean movement. All this means that the 'Brexit' option is now firmly on the national political agenda, and will be the foreseeable future.

\section{References}

Aldrich, R.J. (2008) 'Strategy and Counter-Surprise: Intelligence within BAOR and NATO's Northern Army Group', Journal of Strategic Studies, Vol. 31, No. 1, pp. 89-122.

Beloff, N. (1963) The General Says No: Britain's Exclusion From Europe (Harmondsworth: Penguin).

Berrington, H. and Hague, R. (1998) 'Europe, Thatcherism and Traditionalism: Opinion, Rebellion and the Maastricht Treaty in the Backbench Conservative Party, 1992-1994', West European Politics, Vol. 21, No. 1, pp. 44-71.

Bevir, M., Daddow, O. and Hall, I. (2013) 'Introduction: interpreting British Foreign Policy', British Journal of Politics and International Relations, Vol. 15, No. 2, pp. 163-174. Blair, T. (2002) 'A Clear Course for Europe'. (Cardiff, 28 November). Available at <<http://www.astrid-online.it/Riforma-de/Studi-e-ri/Archivio-2/A.TONY-BLAIR-Speechon-Europe--Cardiff-28.11.2002.pdf >>.

Bogdanor, V. (2005) 'Footfalls Echoing in the Memory. Britain and Europe: The Historical Perspective', International Affairs, Vol. 81, No. 4, pp. 689-701. 
Bratberg, Ø. (2011) 'Ideas, Tradition and Norm Entrepreneurs: Retracing Guiding Principles of Foreign Policy in Blair and Chirac's Speeches on Iraq', Review of International Studies, Vol. 37, No. 1, pp. 327-348.

Brown, G. (2009) speech to the European Parliament. (24 March). Available at <http://image.guardian.co.uk/sys-files/Politics/documents/2009/03/24/brownEP.pdf〉>.

Callaghan, J. (2007) 'Pivotal Powers: The British Labour Party and European Unity Since 1945', Capital and Class, Vol. 93, pp. 199-215.

Cameron, D. EU speech at Bloomberg. (13 January 2013). Available at <<https://www.gov.uk/government/speeches/eu-speech-at-bloomberg>>.

Camps, M. (1966) 'Britain and the European Crisis', International Affairs, Vol. 42, No. 1, pp. 45-54.

Carrington, Lord (1981/82) 'European Political Cooperation: America Should Welcome It', International Affairs, Vol. 58, No. 1, pp.1-6.

Chamberlain, A. (1930) 'Great Britain as a European Power', International Affairs, Vol. 9, No. 2, pp. 180-188.

Crowson, N.J. (2011) Britain and Europe: A Political History Since 1918 (Abingdon: Routledge).

Daddow, O.J. (ed.) (2003) Harold Wilson and European Integration: Britain's Second Application to Join the EEC (London: Frank Cass).

Daddow, O.J. (2004) Britain and Europe Since 1945: Historiographical Perspectives on Integration (Manchester: Manchester University Press).

Daddow, O. (2011) New Labour and the European Union: Blair and Brown's Logic of History (Manchester: Manchester University Press).

Daddow, O. (2012) 'The UK Media and "Europe": From Permissive Consensus to Destructive Dissent', International Affairs, Vol. 88, No. 6, pp. 1219-1236. 
Daniels, P. (1998) 'From Hostility to "Constructive Engagement": The Europeanisation of the Labour Party', West European Politics, Vol. 21, No. 1, pp. 72-96.

Deighton, A. (1998) 'The Last Piece of the Jigsaw: Britain and the Creation of the Western European Union, 1954', Contemporary European History, Vol. 7, No. 2, pp. 181-196.

Ellison, J.R.V. (1996) “’Perfidious Albion”? Britain, Plan G and European Integration, 19551956', Contemporary British History, Vol. 10, No. 4, pp. 1-34.

Forster, A. (2002) Euroscepticism in Contemporary British Politics: Opposition to Europe in the British Conservative and Labour Parties Since 1945 (London: Routledge).

Garton Ash, T. (2001) 'Is Britain European?', International Affairs, Vol. 77, No. 1, pp. 1-13. Gehler, M. and Kaiser, W. (2001) 'Transnationalism and Early European integration: the Nouvelles Equipes Internationales and the Geneva Circle 1947-1957’, The Historical Journal, Vol. 44, No. 3, pp. 773-798.

George, S. (1992) Britain and the European Community: The Politics of Semi-detachment (Oxford: Clarendon Press).

George, S. (1994) An Awkward Partner: Britain in the European Community (2 ${ }^{\text {nd }}$ edition) (New York: Oxford University Press).

Goodlad, G. (2008) 'From Castlereagh to Canning: Continuity and Change in British Foreign Policy', History Today (December), pp. 10-15.

Gowland, D. and Turner, A. (1999) Reluctant Europeans: Britain and European Integration 1945-1998 (London: Longman).

Gowland, A., Turner, A. and Wright, A. (2010) Britain and European Integration Since 1945: On the Sidelines (London: Routledge).

Gstöhl, S. (2002) Reluctant Europeans: Norway, Sweden, and Switzerland in the Process of Integration (London: Lynne Reinner). 
Hall, I. (2006) 'Power Politics and Appeasement: Political Realism in British International Thought, c. 1935-1955', British Journal of Politics and International Relations, Vol. 8, No. 2, pp. 174-192.

Harries, O. (2005) 'Power, Morality, and Foreign Policy', Orbis, No. 1 (Fall), pp. 599-612. Heath, E. (1988) 'European Unity Over the Next Ten Years: From Community to Union', International Affairs, Vol. 64, No. 2, pp. 199-207.

Henig, S. (1975) 'Europe After the Referendum', International Affairs, Vol. 51, No. 4 pp. 487-498.

Jenkins, R. (1983) ‘Britain and Europe: Ten Years of Community Membership’, International Affairs, Vol. 59, No. 2, pp. 147-53.

Kissinger, H.A. (1982) 'Reflections on a Partnership: British and American Attitudes to Postwar Foreign Policy’, International Affairs, Vol. 58, No. 4, pp. 571-587.

Ludlow, N.P. (1997) Dealing with Britain: The Six and the First UK Application to the EEC (Cambridge: Cambridge University Press).

Ludlow, N.P. (2003) ‘A Waning Force: The Treasury and British European Policy, 1955-63', Contemporary British History, Vol. 17, No. 4, pp. 87-104.

Mackintosh, J.P. (1969) "'Britain in Europe"”: Historical Perspective and Contemporary Reality', International Affairs, Vol. 45, No. 2, pp. 246-258.

Major, J. (1994) speech in Leiden. (7 September). Available at $<<$ http://www.johnmajor.co.uk/page1124.html>>.

Morris, N. 'David Cameron Rebukes Michael Gove and Philip Hammond as he Criticises Tories for “Throwing in the Towel” Over Europe and EU Referendum'. Independent (13 May). Available at <<http://www.independent.co.uk/news/uk/politics/david-cameronrebukes-michael-gove-and-philip-hammond-as-he-criticises-tories-for-throwing-in-the-towelover-europe-and-eu-referendum-8613484.html >>. 
Nau, H.R. (2008) ‘Conservative Internationalism', Policy Review, No. 150, pp. 3-44.

Palmer, J. (1982) 'Britain and the EEC: The Withdrawal Option', International Affairs, Vol. 58, No. 4, pp. 638-647.

Peden, G.C. (2013) 'Recognising and Responding to Relative Decline: The Case of Post-war Britain', Diplomacy and Statecraft, Vol. 24, No. 1, pp. 59-76.

Pertusot, V. (2013) 'In Europe, Not Ruled by Europe: Tough Love Between Britain and the EU'. Note de 1-Ifri (March). Available at <<http://www.ifri.org/?page=detailcontribution\&id=7609>>.

Pickard, J. and Parker, G. (2013) 'Stay at heart of Europe, US tells Britain' (10 January). Available at <<http://www.ft.com/cms/s/0/36314b08-5a70-11e2-bc9300144feab49a.html\#axzz2ucA154M5>>. Pym, F. (1982/83) 'British Foreign Policy: Opportunities and Constraints', International Affairs, Vol. 59, No. 1, pp. 1-6.

Quinault, R. (1992) ‘Churchill’s United Europe’, History Today, Vol. 42, No. 6, pp. 9-11. Ringe, N. (2003) 'The Santer Commission resignation crisis: government-opposition dynamics in executive-legislative relations of the EU.' Paper delivered to European Union Studies Association annual meeting. (27-29 March). Available at <<http://aei.pitt.edu/2919/1/156.pdf >>.

Robertson, G. (1998) 'Britain in the New Europe' International Relations, Vol. 66, No. 4, pp. 697-702.

Schaad, M. (1998) 'Plan G - A “Counterblast”? British Policy Towards the Messina Countries, 1956', Contemporary European History, Vol. 7, No. 1, pp. 39-60.

Schmidt, V.A. (2000) 'Democracy and Discourse in an Integrating Europe and a Globalising World', European Law Journal, Vol. 6, No. 3, pp. 277-300. 
Simms, B. (2012) 'Towards a Mighty Union: How to Create a Democratic European

Superpower', International Affairs, Vol. 88, No. 1, pp. 49-62.

Smith H.K. (1950) ‘An American Looks at Europe', International Affairs, Vol. 26, No. 4, pp. 470-476.

Taylor, P.J. (1990) Britain and the Cold War: 1945 as Geopolitical Transition (London: Pinter).

Thatcher, M. (1988) speech at the College of Europe'. (20 September). Available at $<<$ http://www.margaretthatcher.org/document/107332>>.

Turner, M.J. (2010) Britain and the World in the Twentieth Century: Ever Decreasing Circles (London: Continuum UK).

Unwin, P. (1981) 'Britain's Foreign Policy Opportunities Part 2: The European Community', International Affairs, Vol. 57, No. 3, pp. 394-406.

Wall, S. (2008) A Stranger in Europe: Britain and the EU from Thatcher to Blair (Oxford: Oxford University Press).

Wallace, H. (1986) ‘The British Presidency of the European Community’s Council of Ministers: The Opportunity to Persuade', International Affairs, Vol. 62, No. 4, pp. 583-599. Watt, N. (2014) 'Angela Merkel hints at EU Treaty change but sends warning to Britain', Guardian (27 February). Available at <<http://www.theguardian.com/world/2014/feb/27/angela-merkel-eu-treaty-warningbritain>>.

Young, J.W. (2000) Britain and European Unity 1945-1999 (2 ${ }^{\text {nd }}$ edition) (Basingstoke: Macmillan).

Younger, K. (1972) 'Britain in Europe: The Impact on Foreign Policy’, International Affairs, Vol. 48, No. 4, pp. 579-592. 
YouTube (2014) 'The LBC Leaders’ Debate: Nick Clegg vs Nigel Farage' (26 March). Available at <<https://www.youtube.com/watch?v=i6hy8KyedJA〉〉. 